\title{
Thyroglobulin and Microsomal Antibodies in Patients with Insulin Dependent Diabetes Mellitus and their Relatives
}

\author{
Kengo NAGAOKA ${ }^{1}$, TAKehiko SAKURAMI ${ }^{1}$, Noboru NABEYA ${ }^{1}$, \\ Hiroo IMURA ${ }^{1}$ and Shotaro KUNO \\ ${ }^{1}$ 2nd Department of Internal Medicine, Faculty of Medicine, \\ Kyoto University, ${ }^{2}$ Osaka Red Cross Hospital
}

\begin{abstract}
Synopsis
The sera for 88 parents and 9 siblings of 73 patients with insulin dependent diabetes mellitus in childhood and 437 controls matched in age and sex, were tested by the thyroglobulin and microsome-coated tanned red cell hemagglutination test (Fuji-Zoki Co. Tokyo).

None of 73 children with diabetes mellitus had antithyroglobulin antibodies, whereas twelve $(16.4 \%)$ had antimicrosomal antibodies compared with the incidence of $0.4 \%$ and $1.1 \%$, respectively, in 437 controls.

In the parents and siblings of these probands, thyroid antibodies were also found in increased incidence.

The incidence of antimicrosomal antibodies in the 68 mothers was significantly higher than in controls matched for age and sex, but the incidence of the positive thyroid antibodies in the 20 fathers and 9 siblings was not significantly different from that in control populations. The incidence of thyroid antibodies tended to be higher, though not significant, in parents and siblings of diabetic children with positive thyroid antibodies than in those of diabetics with negative ones.

These findings suggest that immunogenetic factors may be responsible for the pathogenesis of some cases of diabetes mellitus in childhood.
\end{abstract}

Environmental and genetic factors have been considered to be of importance in the palhogenesis of diabetes mellitus. In recent years, the association of insulin dependent diabetics: (IDD) with autoimmune diseases and a high incidence of positive organspecific antibodies in IDD have been reported by several investigators (Hecht et al. 1968; Irvine et al. 1970; Nerup et al. 1973). They suggested that an autoimmune process might be responsible for the pathognesis of IDD.

In several autoimmune diseases such as systemic lupus erythematosus (Leonhardt et al. 1964), Hashimoto's thyroiditis (Doniach al. 1965), Graves' disease (Evans et al.

Received July 24, 1978
1967), family studies have revealed increased incidence of thyroid antibodies in relatives. This suggests genetic predisposition in the pathogenesis of autoimmune diseases.

The purpose of the present study was to determine the distribution of thyroid autoantibodies in relatives of patients with diabetes mellitus occurring in childhood.

\section{Materials and Methods}

The patients (probands) were insulin dependent diabetics who attended Kinki region-summer camp of diabetic children in 1975 and 1976 and were 41 girls aged 3 to 20 years and 32 boys aged 8 to 14 years. A total of 97 relatives of these 73 patients who were willing to participate in the tests consisted of 68 mothers, 20 fathers and 9 siblings. They were not associated with diabetes mellitus, thyroid diseases 
nor other autoimmune diseases. The age and sex matched control group ( $\geqq 20$ years) consisted of healthy students, medical staffs, nurses and university workers. Outpatients ( $0-19$ years) who visited Kyoto University Hospital with some complaints were choosen as the disease control group for diabetes mellitus in childhood. Serum was separated as soon as possible after drawing blood and stored at $-20^{\circ} \mathrm{C}$. Circulating antibodies to thyroglobulin and to microsome of thyroid epithelial cells were determined by the tanned red cell hemagglutination method, using a commercially prepared reagent (Fuji Zoki Co. Tokyo). Antithyroglobulin and antimicrosomal antibody titres were regarded as positive if hemagglutination occurred in $1: 160$ dilutions of sera. For titration, $\mathrm{V}$-shaped wells of plastic agglutination trays (Cooke Instruments) were used because the settling pattern of the cells in the cup could be observed from the bottom.

Insulin antiboby was detected by a slight modification of the method of Wright (1966). $0.1 \mathrm{ml}$ of patients serum was diluted by $0.5 \mathrm{ml}$ of $0.1 \mathrm{M} \mathrm{PO}_{4}$. $0.5 \%$ BSA buffer. To this diluted serum were added $1 \mathrm{mU}$ of purified ${ }^{125} \mathrm{I}$-insulin, $5 \mathrm{mU} / \mathrm{ml}$ of cold insulin and stored for $24 \mathrm{hr}$ at $4^{\circ} \mathrm{C}$. Then $10 \%$ Cellulose in $0.1 \mathrm{M} \mathrm{PO}_{4}$ buffer was added to the mixture and centrifuged at $2000 \mathrm{~g}$ for $15 \mathrm{~min}$. Radioactivity of decanted supernatants was measured by the gamma counter. Insulin antibody titres were regarded as positive when $B$ corrected/F values were higher than 0.0375 .

\section{Results}

\section{Thyroid antibodies in diabetics}

None of 73 children with diabetes mellitus had antithyroglobulin antibodies, whereas twelve $(16.4 \%)$ had antimicrosomal antibodies. In contrast, the incidence of positive antithyroglobulin and antimicrosomal antibodies was $0.4 \%$ and $1.1 \%$, respectively, in 437 controls matched in age with patients. (Table 1) The titres of diabetic children having positive antimicrosomal antibodies ranged from $1: 160$ to $1: 10240$.

In 32 males, three $(9.4 \%)$ had antimicrosomal antibodies compared to nine $(21.9 \%)$ in 41 females.

No evident correlation was observed between thyroid antibodies and insulin antibodies. (Table 2)

\section{Thyroid antibodies in relatives}

In the parents and siblings of these probands, the incidence of thyroid antibodies was increased as in the patients. (Fig 1) Antithyroglobulin and antimicrosomal antibodies were positive in $4.5 \%$ and $19.3 \%$, respectively of parents of diabetics.

In addition, one of 9 siblings showed a positive result with antimicrosomal antibodies.

But their titres were not markedly elevated.

Sixteen (94\%) were mothers among 17 parents with positive thyroid antibodies.

Table 1. Incidence of thyroid antibodies in diabetes mellitus in childhood.

\begin{tabular}{ccc}
\hline Group & $\begin{array}{c}\text { Disease controls } \\
\text { no. tested } \\
437\end{array}$ & $\begin{array}{c}\text { Diabetes mellitus } \\
\text { in childhood } \\
\text { no. tested } 73\end{array}$ \\
\hline $\begin{array}{c}\text { Thyroid test } \\
\text { positive } \\
\begin{array}{c}\text { Microsome test } \\
\text { positive }\end{array}\end{array}$ & $2(0.4 \%)$ & $0(0 \%)$ \\
\hline
\end{tabular}

Table 2. Incidence of thyroid antibodies in diabetes mellitus in childhood.

\begin{tabular}{ccc}
\hline Group & \multicolumn{2}{c}{ Diabetes mellitus in childhood } \\
\cline { 2 - 3 } & $\begin{array}{c}\text { Negative } \\
\text { Insulinantibody } \\
51\end{array}$ & $\begin{array}{c}\text { Positive } \\
\text { Insulinantibody } \\
22\end{array}$ \\
\hline $\begin{array}{c}\text { Thyroid test } \\
\text { positive }\end{array}$ & $0(0 \%)$ & $0(0 \%)$ \\
$\begin{array}{c}\text { Microsome test } \\
\text { positive }\end{array}$ & $9(17.6 \%)$ & $3(13.6 \%)$ \\
\hline
\end{tabular}

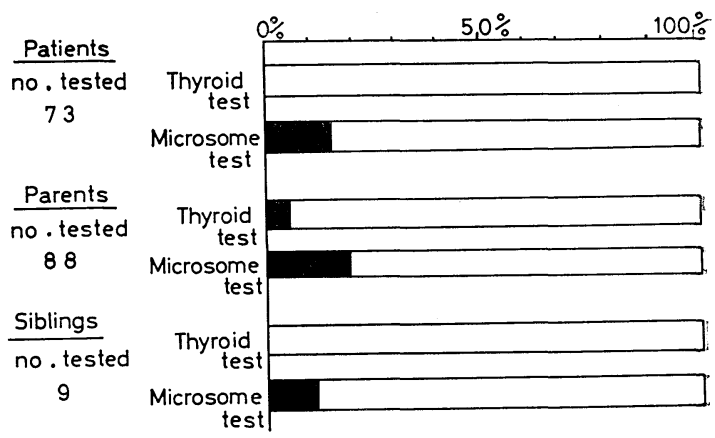

Fig. 1. Incidence of thyroid antibodies among relatives of patients with diabetes mellitus in childhood. 
On the other hand, the incidence of positive antithyroglobulin antibodies in 68 mothers aged between 30 and 49 years was not significantly different from that in 538 age and sex-matched controls $(\mathrm{p}>0.005)$. (Table 3)

This is in contrast with the observation that sixteen of 68 mothers $(23.5 \%)$ had antimicrosomal antibodies compared to $4.1 \%$ in controls $(p<0.005)$. Only one of 20 fathers gave a positive result with antimicrosomal antibodies. The incidence of antithyroglobulin and antimicrosomal antibodies among parents and siblings of probands with positive thyroid antibodies was $5.8 \%$ and $29.4 \%$. (Fig. 2)

These values were higher, though not statistically significant, than the incidence of $3.7 \%$ and $16.2 \%$, respectively, in relatives of thyroid antibody-negative diabetics.

Table 3. Incidence of thyroid antibodies in normal subjects (female 30-49y) and mothers of diabetes mellitus in childhood.

\begin{tabular}{ccc}
\hline Group & $\begin{array}{c}\text { Normal subjects } \\
\text { (female 30-49y) } \\
\text { no. tested } \\
538\end{array}$ & $\begin{array}{c}\text { Mothers of the } \\
\text { probands } \\
\text { no. tested } \\
68\end{array}$ \\
\hline $\begin{array}{c}\text { Thyroid test } \\
\text { positive } \\
\begin{array}{c}\text { Microsome test } \\
\text { positive }\end{array}\end{array}$ & $22(3.1 \%)$ & $4(5.8 \%)$ \\
\hline
\end{tabular}

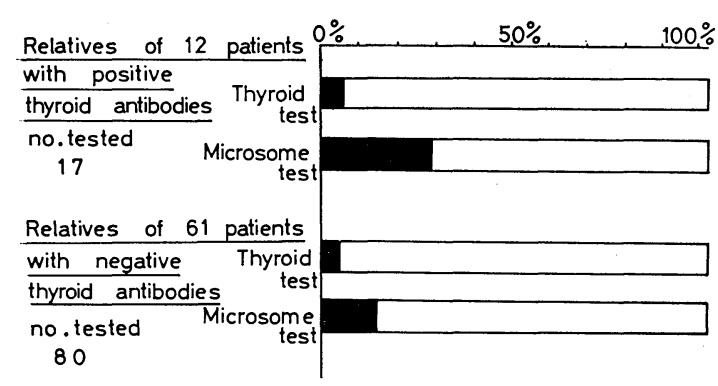

Fig. 2. Incidence of thyroid antibodies among relatives of patients with diabetes mellitus in childhood.

\section{Discussion}

Although the pathogenesis of diabetes mellitus remains undetermined, evidences accumulated in recent years suggest that an autoimmune mechanism is responsible for insulin dependent diabetics (Nerup et al. 1976; Irvine et al., 1977). For example, the increased clinical association of diabetes mellitus with autoimmune diseases, such as Hashimoto's thyroiditis, Addison's disease (Turkington et al., 1967) and pernicious anemia (Munichoodappa et al., 1970) and increased frequencies of organ-specific antibodies such as thyroid, gastric parietal cell antibodies in diabetes mellitus support an autoimmune basis in the pathogenesis of insulin dependent diabetics.

And in Caucasians, a significant positive association between the insulin dependent diabetics and HLA B-8, BW 15 has been reported. However, in Japanese, idiopathic Addison's disease and pernicious anemia are very unusual diseases and HLA B- 8 is almost absent in the Japanese healthy controls.

These findings suggest that the racial difference between Caucasians and Japanese plays a very important role in the incidence of autoimmune disorders. The incidence of thyroid antibodies in Japanese insulin dependent diabetics might be different from those in Caucasians. So we have studied thyroid antibodies in patients with insulin dependent, juvenile-onset diabetics and their relatives, in order to clarify whether or not there exists genetic predisposition for autoimmune diseases in diabetics. The incidence of thyroglobulin antibodies and microsomal antibodies in the control population were $2.3 \%$ and $2.5 \%$ respectively in our previous studies with 2350 apparently normal subjects (Nagaoka et al., 1975). Positive were increased with age, most highly between age 60 to 69 , and about twice more in females than in males. These 
observations agree with the report of Whittingham et al. (1969).

Compared with these results, the incidence of antimicrosomal antibodies in our diabetics was significantly increased, although that of thyroglobulin antibodies was not.

Pettit (1961) observed with the immunofluorescence technique that the incidence of thyroid antibodies was $22 \%$ in childhood diabetes mellitus compared to $1.1 \%$ in normal controls. Using the thyroglobulin and microsome-coated tanned red cell hemagglutination method, we showed that twelve of the 73 children with diabetes mellitus (16.4\%) were positive with antimicrosomal antibodies compared to $1.1 \%$ in 437 disease controls.

Nissley (1973) studied thyroid antibodies in relatives of insulin dependent juvenile diabetics and found that relatives of diabetics with positive thyroid antibodies gave positive results in higher frequency that did those of diabetic patients with nagative thyroid antibodies. Fialkow et al. ([975) reported similar results.

As to the incidence of thyroid antibodies in Japanese mothers with diabetes mellitus in childhood, we observed that it was higher than in the control population and that it was higher in relatives of diabetics with positive microsomal antibodies than in those of diabetics with negative microsomal antibodies. All these results suggest that there are heterogeneous groups in insulin dependent diabetics, one of which has a relationship with thyroid autoimmunity.

Evans et al. (1967) found that thyroid antrbodies in mothers and sisters of thyrotoxic patients were significantly higher than in controls, but not significantly different in fathers and brothers.

An increased incidence of thyroid and gastric autoantibodies in relatives of patients with Hashimoto's thyroiditis was also demonstrated by Doniach (1965). A similar trend was found in relatives of patients with SLE
(Leonhardt et al., 1964).

These findings suggest that genetic factors play an important role in the pathogenesis of autoimmune diseases.

Studies on twins also support the genetic heterogeneity in juvenile diabetics. Pyke et al. (1976) studied 106 pairs of identical twins, one or both of whom had diabetics and found that early-onset diabetic twin pairs were more often discordant that olderonset pairs.

This suggests that genetic factors can not be entirely responsible for the pathogenesis of juvenile diabetics and that environmental factors, such as viral infection may also be important.

Irvine et al. (1977) recently reported that islet cell antibodies were sustainedly positive in insulin dependent diabetics associated with other autoimmune diseases, whereas they were transiently positive in many other diabetics. This observation again supports the heterogeneity of juvenile diabetics. Our present studies lend support to the contention that immunological disorders of genetic basis play an important role in the pathogenesis of at least a part of Japanese juvenile-onset insulin dependent diabetes mellitus.

\section{References}

Doniach, D., I. M. Roitt and K. B. Taylor (1965). Ann. N. Y. Acad. Sci. 124, 605.

Evans, A. W. H., J. C. Woodrow, C. D. M. McDougall, A. R. Chew and R. W. Evans (1967). Lancet 1, 636.

Fialkow, P. J., C. Zavara and R. Nielsen (1975). Ann. Int. Med. 83, 170.

Hecht, A. and H. Gershberg (1968). Metabolism 17, 108.

Irvine, W. J., B. F. Clarke, L. Scarth, D. R. Cullen and L. J. P. Duncan (1970). Lancet 2, 163.

Irvine, W. J., C. J. McCallum, R. S. Gray, C. J. Campbell, L. J. P. Duncan, J. W. Farquhar, H. Vaughan and P. J. Morris (1977). Diabetes 26, 138.

Jacobs, A., C. C. Entwistle, H. Campbell and W. E. Waters (1968). Brit. J. Haematol. 17, 589.

Leonhardt, E. T. G. (1964). Clin. Exp. Immunol. 2, 743. 
Maxon, H. R., K. W. Kreines, R. E. Goldsmith and H. C. Knowles (1975). Arch. Int. Med. 135, 1477. Munichoodappa, C. and G. P. Kozak (1970). Diabetes 19, 719.

Nagaoka, K., N. Nabeya, T. Sakurami, H. Imura (1977). J. Jap. Diab. Soc. 20, 443.

Nerup, J. and C. Binder (1973). Acta Endocrinol. $72,279$.

Nerup, J., O. O. Anderson, M. Christy, P. Platz, L. Ryder, M. Thomsen and A. Sveigaard (1976). Acta Endocrinol. 83 (supple. 205), 167.

Nissley, S. P., A. L. Drash, R. M. Blizzard, M. Sperling and B. Childs (1973). Diabetes 22, 63.
Pettit, M. D., B. H. Landing and G. M. Guest (1961). J. Clin. Endocrinol. 21, 209.

Pyke, D. A. and P. G. Nelson. The genetics of diabetes mellitus. ed Springer-Verlag Berlin, Heidelberg, New York, 194 (1976).

Turkington, R. W. and H. E. Lebovitz (1967). Am. J. Med. 43, 499.

Whittingham, S., W. J. Irvine, I. R. Mackay, S. Marsh and D. C. Cowling (1969). Aust. Ann. Med. 18, 130.

Wright, P. H. and W. J. Mallaisse (1966). Diabetologia 2, 178. 